\title{
OPTIMIZING TILLAGE AND IRRIGATION FOR SUNFLOWER CULTIVATION IN RICE FALLOW* ALFISOLS OF SEMIARID TROPICS
}

\author{
Gurumurthy, P. ${ }^{* *}$, Singa Rao, M. ${ }^{2}$, Bhaskar Reddy, B. ${ }^{3}$ and Reddy, B.N. ${ }^{4}$ \\ ${ }^{1}$ Department of Soil Science and Agricultural Chemistry, Agricultural College, \\ Naira -532185, Srikakulam dt., AndhraPradesh, India \\ ${ }^{2}$ Department of Soil Science and Agricultural Chemistry, College of Agriculture, \\ ANGR Agricultural University, Rajendranagar, Hyderabad-500 030, India \\ ${ }^{3}$ International Research Projects, ANGR Agricultural University, Rajendranagar, \\ Hyderabad-500030, India \\ 4 Directorate of Oilseeds Research, Rajendranagar, Hyderabad-500 030, India
}

Received: January 28, 2007

Accepted: September 10, 2008

\section{SUMMARY}

Studies were conducted on sandy clay loam soil (Typic Haplustalf) to evaluate the effect of five different tillage practices versus four irrigation regimes, $60 \mathrm{~mm}$ irrigation at $\mathrm{IW} / \mathrm{CPE}=0.6,0.8,1.0$ and 1.2 , and their interaction on soil physical changes and performance of sunflower (Helianthus annuus L.) under rice fallow condition. Tillage in general had more positive effect on seedling emergence, growth and yield of sunflower than zero tillage in puddle rice fallows. Deep primary tillage with tractor-drawn disc plow or MB plow produced significantly larger heads with higher test weight, however, secondary tillage with rotavator, either power-tiller- or tractor-drawn, made finer tilth and recorded significantly higher seedling emergence $(80.7 \%)$. Tillage with tractor-drawn disc plow + rotavator (deep-fine tillage) gave significantly higher mean seed yield (1311 $\mathrm{kg} \mathrm{ha}^{-1}$ ) over tractor-drawn MB plow + tractor-drawn cultivator - deep tillage ( $\left.1172 \mathrm{~kg} \mathrm{ha}^{-1}\right)$, ox-drawn desi plow + power-tiller-operated rotavator - shallow fine tillage $\left(1054 \mathrm{~kg} \mathrm{ha}^{-1}\right)$ and ox-drawn desi plow + ox-drawn cultivator - shallow tillage $\left(931 \mathrm{~kg} \mathrm{ha}^{-1}\right)$. The irrigation regime at IW/ $\mathrm{CPE}=1.2$ recorded higher seed yield than $\mathrm{IW} / \mathrm{CPE}=0.6,0.8$ and 1.0. Water use (ETa) by sunflower increased with increase in intensity of tillage and irrigation. WUE was higher in deep tillage practices and in irrigation regime of IW/ $\mathrm{CPE}=0.8$. Deep tillage, besides saving $18 \%$ of irrigation water, resulted in about $24 \%$ higher sunflower seed yield compared with shallow tillage. Interaction effects revealed that significantly higher sunflower growth and yields (both seed and oil) was realized when tillage was done with tractor-drawn disc plow + rotovator coupled with scheduling irrigations at $\mathrm{IW} / \mathrm{CPE}=1.0$ or 1.2 . Tillage with two passages of country plow + once with power-tiller-operated rotavator and scheduling irrigation at IW/CPE $=1.2$ produced significantly superior yields of sunflower than farmers' practice.

* Massive soil structural condition after low land paddy cultivation

** Corresponding author: e-mail: drgurumurthy@yahoo.com 
Key words: tillage, irrigation regimes, water use, water use efficiency, rice fallow - sunflower

\section{INTRODUCTION}

Rice is a staple food in south India (semi-arid tropic climate). It is widely grown under irrigated and rainfed conditions in rainy season. During post-rainy season, rice is grown as second crop under controlled irrigation. However, irrigation water has become scarce of late, especially in tail-end areas of most of the irrigation zones of all major river-systems. For obvious reasons, the government and scientists encourage farmers to cultivate dry crops during post-rainy season in irrigated rice fallows. As the country is facing a shortage of vegetable oils and the oil imports touched \$800 millions (Damodaram and Hegde, 2000), it is more pragmatic to encourage oilseed crops. Sunflower (Helianthus annuus L.), a relatively photoinsensitive short-duration oilseed crop is fast emerging as a very promising succeeding crop to kharif rice in large parts of South India. Land preparation for the preceding crop (puddle rice) however, disturbs the soil structure and associated soil physical characteristics mainly due to the practice which has a negative impact on the performance of the next crop right from the commencement of seedling emergence (Prihar et al., 1985 and Singa Rao et al., 1995). This restricts the yield potential of the crop (Reddy and Reddy, 1989). The problem is ameliorated to a considerable extent by loosening the soil by tillage (Bennie and Botha, 1986). Various tillage practices and irrigation levels have been tried for different crops, however, information on interaction effects of tillage practices and irrigation regimes for sunflower in rice fallows are not available. The present study aims at examining the suitable land preparatory tillage practices and their interactions with various irrigation regimes with the key objective of identifying a tillage system and irrigation regime best suitable for sunflower in rice fallow situations.

\section{MATERIALS AND METHODS}

Field experiments were conducted on transplanted lowland rice fallow at the University Experimental Farm, Acharya N.G. Ranga Agricultural University, Hyderabad $\left(17^{\circ} 19^{\prime}\right.$ north latitude and $78^{\circ} 28^{\prime}$ east longitude and an altitude of 535 $\mathrm{m}$ above MSL)-a semi-arid tropic climate, during rabi for two consecutive years (1998 and 1999). The soil (Typic Haplustalf) was medium deep (50 cm), sandy clay loam with $66.00,12.33$ and $21.67 \%$ of sand, silt and clay, respectively, with initial bulk densities of $1.47(0-15 \mathrm{~cm}), 1.55(15-30 \mathrm{~cm}), 1.59(30-45 \mathrm{~cm}) \mathrm{Mg} \mathrm{m}^{-3}$. The moisture percentages at $-0.03 \mathrm{MPa}$ and $-1.5 \mathrm{MPa}$ pressure were 16.65 and 5.40 by weight, respectively. The soil was neutral ( $\mathrm{pH} 7.54)$, non-saline (E.C. $0.174 \mathrm{~d} \mathrm{Sm}^{-1}$ ), medium in organic carbon $(0.55 \%)$, low in available nitrogen $(223 \mathrm{~kg} / \mathrm{ha})$ and phosphorus (21.4 $\mathrm{kg} \mathrm{P}_{2} \mathrm{O}_{5} / \mathrm{ha}$ ) and medium in available potassium (287 $\mathrm{kg} \mathrm{K} \mathrm{K}_{2} \mathrm{O} / \mathrm{ha}$ ). 
The experiment was laid in a strip plot $(6.6 \mathrm{~m} \times 4.5 \mathrm{~m})$ design with five tillage treatments: $\mathrm{T}_{1^{-}}$zero tillage (dibbling of seeds), $\mathrm{T}_{2^{-}}$two passages with each, oxdrawn desi plow + bullock-drawn three-tyne cultivator-farmers' practice, $\mathrm{T}_{3}$ - two passages of ox-drawn desi plow + one passage of power-tiller-drawn rotavator (modified farmers' practice), $\mathrm{T}_{4}$ - one passage of tractor-drawn MB plow + two passages of tractor-drawn cultivator and $\mathrm{T}_{5^{-}}$one passage with each, tractor-drawn disc plow + rotavator, and four levels of irrigation regime of $60 \mathrm{~mm}$ irrigation at IW/CPE ratio of $0.6\left(\mathrm{I}_{1}\right), 0.8\left(\mathrm{I}_{2}\right), 1.0\left(\mathrm{I}_{3}\right)$ and $1.2\left(\mathrm{I}_{4}\right)$ superimposed on tillage treatments. The treatments were replicated thrice. Tillage treatments were carried out at around $10 \%$ soil moisture content thereby avoiding compaction during tillage operations. The crop (the cultivar Morden) with plant-to-plant and row-to-row distances of $45 \mathrm{~cm}$ and $30 \mathrm{~cm}$, respectively, received $60 \mathrm{~kg} \mathrm{~N}$ (urea in two equal splits as basal dose and at buttoning stage), $60 \mathrm{~kg} \mathrm{P}_{2} \mathrm{O}_{5}$ (SSP as basal dose) and $30 \mathrm{~kg} \mathrm{~K}_{2} \mathrm{O}$ (MoP as basal dose).

Seedling emergence was determined by counting the number of newly emerged seedlings (hills) each in total plot daily. The mean weekly pan evaporation ranged from 4.2 to $8.6 \mathrm{~mm}$ /day (average 6.32) and 4.5 to $9.1 \mathrm{~mm} /$ day (average 6.72) during crop growth period of 1997-98 and 1998-99, respectively. However, there was no precipitation during the crop growing seasons. The mean weekly maximum and minimum temperatures during the crop period ranged from $38.1^{\circ} \mathrm{C}$ to $31.9^{\circ} \mathrm{C}$ and $22.0^{\circ} \mathrm{C}$ to $16.9^{\circ} \mathrm{C}$ and from $41.3^{\circ} \mathrm{C}$ to $31.7^{\circ} \mathrm{C}$ and $27.0^{\circ} \mathrm{C}$ to $14.6^{\circ} \mathrm{C}$ during $1997-98$ and 1998-99, respectively. The mean relative humidity ranged from 89 to 63 and 85 to $52 \%$ during crop growth periods of the first and second years, respectively. The mean weekly bright sunshine hours varied from 10.9 to 9.0 during 1997-98 and from 10.7 to 7.7 during 1998-99.

The IW/CPE ratios of $0.6,0.8,1.0$ and 1.2 received $4,6,8$ and 9 irrigations during 1997-98 with total amounts of irrigation water of 240, 360, 480 and $540 \mathrm{~mm}$, respectively, while during 1998-99 the same treatments were provided 5, 7, 9 and 11 irrigations with total quantities of 300, 420, 540 and $600 \mathrm{~mm}$ irrigation water, respectively. To minimize the interference of water from one treatment to another, $50 \mathrm{~cm}$ wide drains and successive $50 \mathrm{~cm}$ levees were constructed in between the plots. Irrigation water was applied according to the treatments and measured by Vnotch weirs. Soil water availability at different soil depths was monitored by determining soil moisture content gravimetrically at three depths up to $45 \mathrm{~cm}$ of soil using a core sampler (Michael et al., 1977) just before and $24 \mathrm{~h}$ after irrigation. LAI was determined with a planimeter. Growth was expressed in terms of LAI and dry matter (aboveground parts) at harvest. The heads in each net plot were harvested and threshed separately (this was carried out manually). The harvests with border rows eliminated, were threshed, dried to $10 \%$ moisture content and weighed. Oil yield was computed from seed yield and oil content. The experimental data were subjected to the analysis of variance (Panse and Sukathme, 1965). 


\section{RESULTS AND DISCUSSION}

\section{Seedling emergence}

High seedling emergence with rotavator tillage (as secondary tillage) may be attributed to the formation of fine tilth resulting in improved seed-soil-water contact and soil physical conditions that are prerequisites for germination and emergence (Table 1). Similar was the case with rotavator used for secondary tillage $(81.81 \%$ in case of $\mathrm{T}_{5}$ and 79.73 in case of $\left.\mathrm{T}_{3}\right)$ compared with cultivator $\left(67.1 \%\right.$ in case of $\mathrm{T}_{4}$ and $65.86 \%$ in case of $\mathrm{T}_{2}$ ) and zero tillage plots $(57.5 \%)$. The effect of irrigation regimes and their interaction with tillage was not significant for seedling emergence.

Table 1: Effect of tillage practices and irrigation regimes on plant stand, leaf area index (LAI), head diameter and 1000-seed weight of sunflower in rice fallow

\begin{tabular}{lcccccccc}
\hline \multirow{2}{*}{ Treatment } & \multicolumn{2}{c}{$\begin{array}{c}\text { Seedling emergence } \\
\text { (\%) }\end{array}$} & \multicolumn{2}{c}{$\begin{array}{c}\text { Leaf area index } \\
\text { (at flowering) }\end{array}$} & \multicolumn{2}{c}{$\begin{array}{c}\text { Head diameter } \\
\text { (cm) }\end{array}$} & \multicolumn{2}{c}{$\begin{array}{c}\text { 1000-seed weight } \\
\text { (g) }\end{array}$} \\
\cline { 2 - 9 } & $97-98$ & $98-99$ & $97-98$ & $98-99$ & $97-98$ & $98-99$ & $97-98$ & $98-99$ \\
\hline Tillage practice (T) & & & & & & & \\
$\mathrm{T}_{1}$ & 58.64 & 56.36 & 1.78 & 1.74 & 11.5 & 10.7 & 35.53 & 34.69 \\
$\mathrm{~T}_{2}$ & 66.36 & 65.36 & 2.09 & 2.07 & 13.5 & 13.1 & 37.21 & 36.99 \\
$\mathrm{~T}_{3}$ & 79.10 & 80.45 & 2.50 & 2.36 & 14.1 & 13.7 & 37.93 & 38.04 \\
$\mathrm{~T}_{4}$ & 68.18 & 66.00 & 2.74 & 2.60 & 16.4 & 16.0 & 40.96 & 40.23 \\
$\mathrm{~T}_{5}$ & 80.91 & 82.72 & 3.02 & 2.86 & 16.1 & 15.7 & 41.62 & 40.28 \\
\hline Irrigation regime (M) & & & & & & & \\
$\mathrm{I}_{1}$ & 69.42 & 69.72 & 1.93 & 1.87 & 12.6 & 11.8 & 34.62 & 34.87 \\
$\mathrm{I}_{2}$ & 71.65 & 72.33 & 2.35 & 2.23 & 13.9 & 13.2 & 37.22 & 37.58 \\
$\mathrm{I}_{3}$ & 71.29 & 70.29 & 2.67 & 2.55 & 15.2 & 14.8 & 40.25 & 39.10 \\
$\mathrm{I}_{4}$ & 70.23 & 68.38 & 2.77 & 2.67 & 15.7 & 15.6 & 42.51 & 40.63 \\
\hline $\mathrm{CD}(\mathrm{P}=0.05)$ & & & & & & & & \\
$\mathrm{T}$ & 4.88 & 4.52 & 0.17 & 0.26 & 0.63 & 1.00 & 1.50 & 1.09 \\
$\mathrm{M}$ & $\mathrm{NS}$ & $\mathrm{NS}$ & 0.21 & 0.18 & 0.53 & 0.91 & 0.95 & 1.21 \\
\hline
\end{tabular}

$\mathrm{T}_{1}$ - zero tillage (dibbling of seeds),

$T_{2}$ - two passages of each, ox-drawn desi plow + ox-drawn three-tyne cultivator (farmers' practice),

$\mathrm{T}_{3}$ - two passages of ox-drawn desi plow + one passage of power-tiller-drawn rotavator (modified farmers' practice),

$\mathrm{T}_{4}$ - one passage of tractor-drawn MB plow + two passages of tractor-drawn cultivator,

$\mathrm{T}_{5}$ - one passage of tractor-drawn disc plow + rotavator

Irrigation regimes of $60 \mathrm{~mm}$ irrigation at IW/CPE ratio of $0.6\left(I_{1}\right), 0.8\left(\mathrm{I}_{2}\right), 1.0\left(\mathrm{I}_{3}\right)$ and $1.2\left(\mathrm{I}_{4}\right)$

\section{Leaf area index}

Tillage, irrigation regimes and their interaction affected the leaf area index of sunflower (Table 1). At 60 DAS, higher leaf area index (LAI) resulted when the soil was tilled to deeper depths and made to fine tilth $\left(\mathrm{T}_{5}\right)$ as compared with the other treatments. Finer tilth coupled with deep plowing $\left(\mathrm{T}_{5}\right)$ resulted in higher plant population (Table 1) and higher plant growth producing high leaf area index. Similar results were reported for mungbean (IARI, 1984) and groundnut (Khan, 1984). Irri- 
gation given at shorter intervals by adopting relatively higher irrigation regimes (IW/ $\mathrm{CPE}=1.0$ and 1.2) resulted in higher leaf area index compared with the schedules at longer intervals (IW/CPE $=0.6$ and 0.8$)$.

\section{Size of sunflower heads}

Significantly largest mean head size of $16.2 \mathrm{~cm}$ was registered (Table 1) in deep tillage with tractor-drawn $\mathrm{MB}$ plow + cultivator $\left(\mathrm{T}_{4}\right)$ which was almost similar to tractor-drawn disc plow + rotavator $\left(\mathrm{T}_{5}\right)$. Sunflower root extension to deeper soil layers and increased soil water retention under deep tillage practices, which in turn resulted in higher crop growth, was responsible for the production of larger heads. The irrigation scheduled at IW/CPE $=1.2\left(\mathrm{I}_{4}\right)$ registered significantly large heads mainly due to optimum water supply in that particular schedule. Increase in sunflower head size with intensity of irrigation frequency was also reported earlier (Paul and Yadav, 1974; Singh et al., 1995).

\section{0-seed weight}

Both tillage practices and soil moisture regimes significantly affected sunflower seed test weight. The test weight was significantly superior in deep tillage practices $\left(\mathrm{T}_{4}\right.$ and $\left.\mathrm{T}_{5}\right)$ compared with shallow tillages $\left(\mathrm{T}_{2}\right.$ and $\left.\mathrm{T}_{3}\right)$ and zero tillage $\left(\mathrm{T}_{1}\right)$. Wettest soil moisture regime $\left(\mathrm{I}_{4}\right)$ produced significantly higher test weight than the others $\left(\mathrm{I}_{1}, \mathrm{I}_{2}\right.$ and $\left.\mathrm{I}_{3}\right)$. Sufficient water availability in deep tillage practices and intensive irrigation regimes facilitated proper translocation of photosynthates resulting in proper seed filing and in turn higher 1000-seed weight. The results are in conformity with those of Singh et al. (1995).

\section{Total dry matter accumulation}

Favorable soil conditions, i.e., deep-fine tillage, and high available moisture capacity created with tractor-drawn disc plow once + rotovator twice $\left(\mathrm{T}_{5}\right)$ resulted in high dry matter accumulation (Table 2). Increase in irrigation regime from IW/ CPE 0.6 to 1.2 significantly increased the dry matter accumulation. This could be attributed to the availability of relatively high water level in the soil throughout irrigation cycles in the plots irrigated with IW/CPE ratios of 1.0 and 1.2. On the other hand, in $\mathrm{IW} / \mathrm{CPE}=0.8$ and $\mathrm{IW} / \mathrm{CPE}=0.6$ moisture regimes, growing plants experienced relatively high soil water stress, hence the lower dry matter accumulation. The interaction effects of tillage and irrigation regimes significantly affected the dry matter production, which appears to be due to high seedling emergence and relatively better growth at the initial stage of crop in deep-fine tillage $\left(\mathrm{T}_{5}\right)$ coupled with frequent water supply (IW/CPE ratios of 1.2 and 1.0).

\section{Seed and oil yield}

The tillage treatment with tractor-drawn disc plow once + rotovator $\left(\mathrm{T}_{5}\right)$ produced on average $80,40,25$ and $14 \%$ higher seed yield over zero tillage $\left(\mathrm{T}_{1}\right)$, ox- 
Table 2: Effect of tillage practices and irrigation regimes on dry matter (at harvest), seed yield and oil yield sunflower under rice fallows

\begin{tabular}{|c|c|c|c|c|c|c|c|c|c|c|}
\hline & \multicolumn{5}{|c|}{ 1997- 1998} & \multicolumn{5}{|c|}{ 1998- 1999} \\
\hline & \multicolumn{5}{|c|}{ Irrigation regime } & \multicolumn{5}{|c|}{ Irrigation regime } \\
\hline & $\mathrm{I}_{1}$ & $\mathrm{I}_{2}$ & $\mathrm{I}_{3}$ & $\mathrm{I}_{4}$ & Mean & $I_{1}$ & $\mathrm{I}_{2}$ & $I_{3}$ & $\mathrm{I}_{4}$ & Mean \\
\hline Tillage (T) & \multicolumn{10}{|c|}{ Dry matter kgha- ${ }^{-1}$} \\
\hline $\mathrm{T}_{1}$ & 1626 & 1952 & 2131 & 2178 & 1973 & 1536 & 1746 & 2040 & 2168 & 1872 \\
\hline $\mathrm{T}_{2}$ & 1847 & 2280 & 2576 & 2664 & 2342 & 1802 & 2195 & 2490 & 2639 & 2281 \\
\hline $\mathrm{T}_{3}$ & 2087 & 2580 & 2857 & 2952 & 2619 & 1993 & 2527 & 2862 & 3036 & 2604 \\
\hline $\mathrm{T}_{4}$ & 2210 & 2706 & 3065 & 3154 & 2745 & 2253 & 2767 & 3052 & 3101 & 2793 \\
\hline $\mathrm{T}_{5}$ & 2490 & 3079 & 3465 & 3545 & 3145 & 2493 & 2990 & 3287 & 3407 & 3044 \\
\hline \multirow[t]{2}{*}{ Mean } & 2052 & 2522 & 2810 & 2899 & & 2015 & 2445 & 2743 & 2870 & \\
\hline & \multicolumn{10}{|c|}{ Seed yield kgha ${ }^{-1}$} \\
\hline $\mathrm{T}_{1}$ & 557 & 742 & 838 & 876 & 753 & 510 & 633 & 767 & 834 & 686 \\
\hline $\mathrm{T}_{2}$ & 693 & 924 & 1097 & 1156 & 967 & 651 & 838 & 1004 & 1085 & 894 \\
\hline $\mathrm{T}_{3}$ & 774 & 1036 & 1228 & 1305 & 1086 & 718 & 975 & 1158 & 1256 & 1022 \\
\hline $\mathrm{T}_{4}$ & 881 & 1176 & 1315 & 1398 & 1192 & 851 & 1131 & 1285 & 1341 & 1152 \\
\hline $\mathrm{T}_{5}$ & 996 & 1321 & 1528 & 1584 & 1357 & 944 & 1248 & 1392 & 1478 & 1265 \\
\hline \multirow[t]{2}{*}{ Mean } & 780 & 1040 & 1201 & 1264 & & 735 & 965 & 1121 & 1199 & \\
\hline & \multicolumn{10}{|c|}{ Oil yield kgha-1 } \\
\hline $\mathrm{T}_{1}$ & 200 & 270 & 312 & 331 & 278 & 174 & 225 & 280 & 309 & 247 \\
\hline $\mathrm{T}_{2}$ & 254 & 345 & 433 & 490 & 373 & 234 & 310 & 389 & 428 & 340 \\
\hline $\mathrm{T}_{3}$ & 281 & 395 & 494 & 532 & 426 & 261 & 366 & 449 & 499 & 394 \\
\hline $\mathrm{T}_{4}$ & 346 & 490 & 561 & 597 & 499 & 323 & 453 & 531 & 556 & 466 \\
\hline $\mathrm{T}_{5}$ & 394 & 532 & 650 & 676 & 566 & 359 & 504 & 570 & 611 & 511 \\
\hline Mean & 295 & 407 & 492 & 519 & & 270 & 372 & 444 & 481 & \\
\hline
\end{tabular}

$\mathrm{T}_{1}$ - zero tillage (dibbling of seeds),

$\mathrm{T}_{2}$ - two passages of each, ox-drawn desi plow + ox-drawn three-tyne cultivator (farmers' practice), $\mathrm{T}_{3}$ - two passages of ox-drawn desi plow + one passage of power-tiller-drawn rotavator (modified farmers' practice),

$\mathrm{T}_{4}$ - one passage of tractor-drawn MB plow + two passages of tractor-drawn cultivator,

$\mathrm{T}_{5-}$ one passage of tractor-drawn disc plow + rotavator

Irrigation regimes of $60 \mathrm{~mm}$ irrigation at IW/CPE ratio of $0.6\left(\mathrm{I}_{1}\right), 0.8\left(\mathrm{I}_{2}\right), 1.0\left(\mathrm{I}_{3}\right)$ and $1.2\left(\mathrm{I}_{4}\right)$

Tillage $(T)$

$\mathrm{CD}(\mathrm{P}=0.05)$

Dry matter Seed yield Oil yield Dry matter Seed yield Oil yield

Irrigation regime (I)

$C D(P=0.05)$

169

82

32

111

63

27

$T$ at I

$C D(P=0.05)$

132

69

29

98

58

39

I at $T$

272

125

58

171

108

50

$C D(P=0.05)$

212

79

45

142

82

41 
drawn wooden plow twice + cultivator twice $\left(\mathrm{T}_{2}\right)$, ox-drawn wooden plow twice + power-tiller-drawn rotovator twice $\left(\mathrm{T}_{3}\right)$ and tractor-drawn mould plow once + cultivator twice $\left(\mathrm{T}_{4}\right)$, respectively, in 1997-98 while the respective percentages in 199899 were 84, 45, 24 and 10\% (Table 2). Similar effect of the tillage treatments was observed with oil yield of sunflower. These changes were attributed to changes in the amount and distribution of water in the soil profile and to changes in plant rooting patterns. Irrigation at IW/CPE ratio of 1.2 resulted in 5.2, 21.5 and $62 \%$ higher yield over IW/CPE of 1.0, 0.8 and 0.6, respectively, in 1997-98 and the respective percentages for 1998-99 were 7.0, 24.2 and 63.1\%. Talati and Mehta (1963) reported that grain yield of pearl millet on sandy loam soils of Gujarat, India, was more than double with deep tillage than with shallow tillage. Scheduling $6 \mathrm{~cm}$ irrigation at IW/CPE $=1.0$ also recorded significantly highest yield compared with 0.6 and 0.8 , and was at par with the highest soil water regime ( $\mathrm{IW} / \mathrm{CPE}=1.2$ ). Interaction effects of tillage and irrigation regimes showed that 180 (1997-98) to $240 \mathrm{~mm}$ (1998-99) of irrigation water were saved by providing deep tillage $(26 \mathrm{~cm})$ either with disc plow or with mouldboard plow compared with shallow tillage $(11 \mathrm{~cm})$ while maintaining yield at optimum levels. The combination of deep-fine tillage and frequent irrigations resulted in significantly high seed yield of $1531 \mathrm{~kg} / \mathrm{ha}$ (Table 2). This could be attributed to higher plant water status resulting in higher net photosynthetic activity (Upreti and Sirohi, 1985). Although both of the deep tillage treatments $\left(\mathrm{T}_{4}\right.$ and $\mathrm{T}_{5}$ ) produced large heads and high seed test weight, similar individual plant growth and seed yield, the total seed and oil yield difference was significant because of the significant difference in plant stand. This difference in plant stand was the result of finer tilth achieved with secondary tillage with rotovator.

\section{Water use (WU)}

The water use (ETa) of the crop under different tillage practices and irrigations regimes presented in Table 3 indicated that evapotranspiration (ETa) of sunflower under different tillage and irrigation combinations varied from 262 to $495 \mathrm{~mm}$. The average ETa of $\mathrm{T}_{1}, \mathrm{~T}_{2}, \mathrm{~T}_{3}, \mathrm{~T}_{4}$ and $\mathrm{T}_{5}$ were found to be $354,374,391,403$ and 416 $\mathrm{mm}$, respectively. Increased water use with intensity of tillage contributed to favorable soil physical environment for root penetration, air permeability and highe moisture storage in soil. Better root expansion with deep tillage $\left(\mathrm{T}_{5}\right.$ and $\left.\mathrm{T}_{4}\right)$ increased the capability of plants to extract more water from subsoil (Chaudhury et al., 1985 and Arora et al., 1991) resulting in greater water use. The mean water use in IW/ $\mathrm{CPE}=1.2$ moisture regime was highest $(471 \mathrm{~mm})$ compared with $\mathrm{IW} / \mathrm{CPE}=0.6$ (289mm), $0.8(356 \mathrm{~mm})$ and $1.0(433 \mathrm{~mm})$. Sufficient water availability throughout the crop period under intense irrigation regime enabled the crop to use more water. 
Table 3: Effect of tillage treatments and irrigation regimes on water use efficiency $\left(\mathrm{kg} \mathrm{ha}^{-1} \mathrm{~mm}^{-1}\right)$ of sunflower (pooled data of 1998 and 1999)

\begin{tabular}{lccccc}
\hline \multirow{2}{*}{ Tillage (T) } & \multicolumn{5}{c}{ Irrigation regime } \\
\cline { 2 - 6 } & $\mathrm{I}_{1}$ & $\mathrm{I}_{2}$ & $\mathrm{I}_{3}$ & $\mathrm{I}_{4}$ & Mean \\
\hline $\mathrm{T}_{1}$ & $2.05(262)$ & $2.16(320)$ & $2.08(393)$ & $1.97(439)$ & $2.07(354)$ \\
$\mathrm{T}_{2}$ & $2.45(278)$ & $2.60(342)$ & $2.55(414)$ & $2.45(460)$ & $2.51(374)$ \\
$\mathrm{T}_{3}$ & $2.62(290)$ & $2.84(356)$ & $2.73(438)$ & $2.69(478)$ & $2.72(391)$ \\
$\mathrm{T}_{4}$ & $2.89(303)$ & $3.11(373)$ & $2.89(452)$ & $2.80(483)$ & $2.92(403)$ \\
$\mathrm{T}_{5}$ & $3.14(313)$ & $3.34(390)$ & $3.14(467)$ & $3.11(495)$ & $3.18(416)$ \\
\hline Mean & $2.62(289)$ & $2.81(356)$ & $2.68(433)$ & $2.60(471)$ & \\
\hline
\end{tabular}

(Figures in parenthesis are seasonal crop water use in $\mathrm{mm}$ )

$\mathrm{CD}(\mathrm{P}=0.05)$

\begin{tabular}{ll}
\hline Tillage $(\mathrm{T})$ & 0.18 \\
Irrigation regime $(\mathrm{I})$ & 0.13 \\
Interaction & \\
$\mathrm{T}$ at I & 0.22 \\
$\mathrm{I}$ at $\mathrm{T}$ & 0.15 \\
\hline
\end{tabular}

\section{Water use efficiency (WUE)}

Deep-fine tilth obtained in $\mathrm{T}_{5}$ recorded highest water use efficiency of $3.18 \mathrm{~kg}$ $\mathrm{ha}^{-1} \mathrm{~mm}^{-1}$ which was significantly superior to $\mathrm{T}_{1}\left(2.07 \mathrm{~kg} \mathrm{ha}^{-1} \mathrm{~mm}^{-1}\right), \mathrm{T}_{2}(2.51 \mathrm{~kg}$ $\left.\mathrm{ha}^{-1} \mathrm{~mm}^{-1}\right), \mathrm{T}_{3}\left(2.72 \mathrm{~kg} \mathrm{ha}^{-1} \mathrm{~mm}^{-1}\right)$ and $\mathrm{T}_{4}\left(2.92 \mathrm{~kg} \mathrm{ha}^{-1} \mathrm{~mm}^{-1}\right)$. The irrigation regimes at IW/CPE of $0.8\left(\mathrm{I}_{2}\right)$ resulted in highest WUE $\left(2.81 \mathrm{~kg} \mathrm{ha}^{-1} \mathrm{~mm}^{-1}\right)$. The interaction effect of the tillage practices and irrigations was significant. Deep tillage with tractor-drawn disc plow + rotavator $\left(\mathrm{T}_{5}\right)$ in combination of IW/CPE $=0.8$ was the most efficient with regard to WUE $\left(3.34 \mathrm{~kg} \mathrm{ha}^{-1} \mathrm{~mm}^{-1}\right)$. Under shallow tillage conditions $\left(T_{3}\right.$ and $T_{2}$ ), the WUE did not differ significantly for $I_{2}, I_{3}$ and $I_{4}$, however, highest WUE with deep tillage $\left(\mathrm{T}_{4}\right.$ and $\left.\mathrm{T}_{5}\right)$ was recorded with irrigation combination of $\mathrm{IW} / \mathrm{CPE}=0.8$. The soil in the deep tillage practices loosened to deeper depths, the improved soil water retention making moisture available to sunflower crop throughout the cropping period. These observations indicate that sunflower responds up to IW/CPE of 1.2 under shallow tillage conditions in rice fallows. Similar observations were also reported by Bhushan et al. (1977) for Brassica compestris var. toria on silty loam soils and Salih et al. (1998) for cotton on clayey soils.

\section{Benefit/cost ratio}

In general, the tillage practices showed their superiority over zero tillage under rice fallows in benefit/cost ratio (Table 4). Scheduling irrigations at IW/CPE of 1.2 $\left(\mathrm{M}_{4}\right)$ resulted in highest B : C ratio of 2.35 in the first year and 2.18 in the second year. Critical examination of net returns and $\mathrm{B}: \mathrm{C}$ ratio reveals that, under deep tillage conditions $\left(\mathrm{T}_{5}\right.$ and $\mathrm{T}_{4}$ ), the response to irrigation was up to IW/CPE $=1.0$, how- 
ever, the crop responded up to $\mathrm{IW} / \mathrm{CPE}=1.2$ under shallow and zero tillage conditions. The deep and fine tillage $\left(\mathrm{T}_{5}\right)$ resulted in highest $\mathrm{B}: \mathrm{C}$ ratio. At IW/ $\mathrm{CPE}=1.0$ and $1.2, \mathrm{~T}_{4}$ and $\mathrm{T}_{3}$ tillages did not differ much in the $\mathrm{B}: \mathrm{C}$ ratio, however, the difference due to these tillage practices $\left(T_{4}\right.$ and $\left.T_{3}\right)$ was wide under limited moisture supply (IW/CPE $=0.6$ and 0.8 ). It confirms the overall superiority of deep tillage treatments under limited water supply as stated by Vittal (1983).

Table 4: Effect of tillage treatments and irrigation regimes on benefit/cost ratio of post-rainy season sunflower under rice fallows

\begin{tabular}{|c|c|c|c|c|c|c|c|c|c|c|}
\hline \multirow{4}{*}{ Treatment } & \multicolumn{10}{|c|}{ Benefit - cost ratio } \\
\hline & \multicolumn{5}{|c|}{ 1997- 98} & \multicolumn{5}{|c|}{ 1998- 99} \\
\hline & \multicolumn{5}{|c|}{ Irrigation regime } & \multicolumn{5}{|c|}{ Irrigation regime } \\
\hline & $I_{1}$ & $\mathrm{I}_{2}$ & $\mathrm{I}_{3}$ & $\mathrm{I}_{4}$ & Mean & $I_{1}$ & $\mathrm{I}_{2}$ & $\mathrm{I}_{3}$ & $\mathrm{I}_{4}$ & Mean \\
\hline \multicolumn{11}{|l|}{ Tillage (T) } \\
\hline $\mathrm{T}_{1}$ & 1.19 & 1.17 & 1.18 & 1.69 & 1.31 & 1.06 & 1.27 & 1.48 & 1.56 & 1.34 \\
\hline $\mathrm{T}_{2}$ & 1.48 & 1.90 & 2.16 & 2.23 & 1.94 & 1.36 & 1.68 & 1.94 & 2.02 & 1.75 \\
\hline $\mathrm{T}_{3}$ & 1.59 & 2.04 & 2.33 & 2.43 & 2.10 & 1.44 & 1.88 & 2.15 & 2.25 & 1.93 \\
\hline $\mathrm{T}_{4}$ & 1.67 & 2.15 & 2.32 & 2.42 & 2.14 & 1.58 & 2.03 & 2.23 & 2.25 & 2.02 \\
\hline $\mathrm{T}_{5}$ & 1.82 & 2.33 & 2.60 & 2.65 & 2.35 & 1.86 & 2.13 & 2.33 & 2.39 & 2.18 \\
\hline Mean & 1.55 & 1.92 & 2.12 & 2.28 & & 1.46 & 1.80 & 2.03 & 2.10 & \\
\hline
\end{tabular}

\section{CONCLUSION}

Deep-fine tilth obtained by one passage of tractor-drawn disc plow + rotavator resulted in significantly higher seedling emergence, crop growth, WUE, seed and oil yield of sunflower. Deep- fine tillage at irrigation regime of $\mathrm{IW} / \mathrm{CPE}=1.0$ was the best for sunflower production in rice fallows both in terms of yield and WUE. Deep tillage saved irrigation water to the extent of $18 \%$, in addition to increasing sunflower seed yield by $24 \%$. Partial modification of farmers' tillage practice by substituting secondary tillage of ox-drawn three-tyne cultivator with power-tiller-drawn rotavator significantly improved seed and oil yield of sunflower.

\section{ACKNOWLEDGEMENTS}

The authors render thanks to Dr. S.N Sudhakarababu and Dr. D.K. Sarkar for their help in getting the paper to the final form.

\section{NOTES}

Gurumurthy, P., Assistant professor, Dept. of Soil Sci. and Agricultural Chemistry, Agricultural College, Naira -532185, Srikakulam dt., Andhra Pradesh, India, e-mail : drgurumurthy@yahoo.com 
Singa Rao, M., Professor of Soil Physics, Dept. of Soil Sci. and Agricultural Chemistry, College of Agriculture, Rajendranagar, Hyderabad - 500 030, India

Bhaskar Reddy, B., Director, International Research Projects, ANGR Agricultural University, Rajendranagar, Hyderabad- 500030, India.

Reddy, B.N., Principal Scientist (Agronomy) and Head (Crop Production Division), Directorate of Oilseeds Research, Rajendranagar, Hyderabad- 500 030, India, e-mail: reddybnr@rediffmail.com

\section{REFERENCES}

Arora, V.K., Gajri, P.R. and Prihar, S.S., 1991. Tillage effects on corn in sandy soils in relation to water retentivity, nutrient and water management and seasonal evaporativity. Soil and Tillage Research 21: 1-21.

Bennie, A.T.P. and Botha, F.J.P., 1986. Effect of deep tillage and controlled traffic on root growth, water use efficiency and yield of irrigated maize and wheat. Soil and Tillage Research 7: 85-95.

Bhushan, L.S., Varade, S.B. and Gupta, C.P., 1977. Influence of clod size on soil temperature, moisture tension and seedling emergence of field crops. Journal of Agricultural Engineering 11(4): 20-24.

Chaudhary, M.R., Gajri, P.R., Prihar, S.S. and Romesh Khera, 1985, Effect of deep tillage on soil physical properties and maize yields on coarse textured soils. Soil and Tillage Research 6: 31-44.

Damodaram, T. and Hegde, D.M., 2000. Oilseeds Situations-A Statistical Compendium. Directorate of Oilseeds Research (ICAR), Hyderabad, India.

IRRI, 1984. Tillage and management of soil physical conditions. In: IRRI Annual Report for 1983. International Rice Research Institute, Los Banos, Phillippines, pp. 315-324.

Michael, A.M., Hukkeri, S.B. and Singh, N.P., 1977. Estimating water requirement of crops. Indian Agricultural Research Institute, Monograph No.4, New Delhi, pp. 91-162.

Panse, V.G. and Sukhatme, P.V., 1978. Statistical methods for agricultural workers. Indian Council of Agricultural Research, New Delhi, pp. 1-186.

Paul, M. and Yadav, S.C., 1974. Response of sunflower varieties to soil moisture regimes and nitrogen levels. Indian Journal of Agricultural Research 8: 157-161.

Prihar, S.S., Ghildyal, B.P., Painuli, D.K. and Sur, H.S., 1985. Physical properties of mineral soils affecting rice- based cropping systems. In: Soil Physics and Rice. International Rice Research Institute, Los Banos, Phillippines, pp. 57-70.

Reddy, G.H.S. and Reddy, A.A., 1989. Causes of low yields of groundnut in six districts of AndhraPradesh. Survey Report, Acharya N.G. Ranga Agricultural University (formerly Andhra Pradesh Agricultural University), Hyderabad, India.

Salih, A.A., Babikir, H.M. and Ali, S.A.M., 1998. Preliminary observations on effects of tillage systems on soil physical properties, cotton root growth and yield in Gezira Scheme, Sudan. Soil and Tillage Research 46: 187-191.

Singa Rao, M., Prabhu Prasadini, R., Nagender Rao, C. and Jayasree, G., 1995. Soil physical constraints and their management for increasing crop production in Andhra Pradesh. Highlights of Research during 1967-1994, Andhra Pradesh Agricultural University, Hyderabad.

Singh, V., Sharma, S.K., Verma, B.L. and Singh, B., 1995. Response of rainy season sunflower (Helianthus annuus L.) to irrigation and nitrogen under north western Rajasthan. Indian Journal of Agronomy 40(2): 239-242.

Talati, N.R. and Mehta, B.V., 1963. Effect of deep and shallow tillage on nutrient release, moisture conservation and yield of pearl millet in Goradu soils of Anand. Journal of the Indian Society of Soil Science, 11(1): 9-16.

Upreti, D.C. and Sirohi, G.S., 1985. Effect of water stress on photosynthesis and water relations of wheat varieties. Indian Journal of plant Physiology 28: 107-114.

Vittal, K.P.R., Vijayalakshmi, K. and Rao, U.M.B., 1983. Effect of deep tillage on dryland crop production in red soils of India. Soils and Tillage Research 3(4): 377-384. 


\title{
OPTIMIZACIÓN DE LA LABRANZA Y EL RIEGO PARA EL CULTIVO DE GIRASOL EN LOTES DE BARBECHO DE ARROZ (ALFISOLES) DE TRÓPICOS SEMIÁRIDOS
}

\author{
RESUMEN
}

\begin{abstract}
Se condujeron estudios en un suelo areno arcillo limoso (Haplustalf típico) para evaluar la influencia de cinco prácticas de labranza diferentes y cuatro regímenes de riego $(60 \mathrm{~mm}$ de riego a $\mathrm{IW} / \mathrm{CPE}=0.6,0.8,1.0$ y 1.2$)$ y su interacción con los cambios físicos del suelo y el comportamiento del cultivo de girasol (Helianthus annuus L.) bajo una condición de barbecho de arroz. En términos generales, la labranza tuvo un efecto positivo sobre la emergencia de plántulas, crecimiento y rendimiento de girasol en comparación con la labranza cero en rastrojos de arroz. La labranza profunda primaria con arado de disco o MB tirado por tractor produjo capítulos significativamente más grandes con mayor peso hectolítrico. Sin embargo, la labranza secundaria con rotavator, ya sea autopropulsada o tirada por tractor, realizó un trabajo más fino y se registró una emergencia de plántula significativamente mayor $(80,7 \%)$. La labranza con arado de discos tirado por tractor + rotavator (labranza profunda y fina) produjo un rendimiento medio significativamente mayor (1311 kg ha-1) sobre el arado MB tirado por tractor + labranza profunda con cultivador tirado por tractor $\left(1172 \mathrm{~kg} \mathrm{ha}^{-1}\right)$, arado tirado por bueyes + labranza fina superficial con rotavator autopropulsado (1054 $\mathrm{kg} \mathrm{ha}^{-1}$ ) y arado tirado por bueyes + labranza superficial con cultivador conducido por bueyes $\left(931 \mathrm{~kg} \mathrm{ha}^{-1}\right)$. El régimen de riego de $\mathrm{IW} / \mathrm{CPE}=1.2$ registró un mayor rendimiento en semilla que con $\mathrm{IW} / \mathrm{CPE}=0.6,0.8$ y 1.0. El uso del agua (ETa) por el cultivo de girasol aumentó con el incremento en intensidad de labranza y riego. La eficiencia en el uso del agua fue mayor en prácticas de labranza profunda y con un régimen de riego de $\mathrm{IW} / \mathrm{CPE}=0.8$. La labranza profunda además permitió ahorrar un $18 \%$ del agua de riego resultando en alrededor de un $24 \%$ de incremento en el rendimiento de semilla de girasol en comparación con la labranza superficial. Los efectos de interacción revelaron que el crecimiento y rendimiento de girasol significativamente mayores (tanto en semilla como en aceite) se obtuvo cuando la labranza se realizó con arado de disco tirado por tractor + rotavator asociado con esquemas de riego a IW/CPE $=1.0 \mathrm{o}$ 1.2. La labranza con dos pasadas de arado + una con rotavator autopropulsado y un esquema de irrigación a IW/CPE $=1.2$ produjo rendimientos de girasol significativamente superiores a las prácticas comunes de los productores.
\end{abstract}

\section{OPTIMALISATION DE LA CULTURE DU SOL ET DE L'IRRIGATION POUR LA PRODUCTION DU TOURNESOL APRÈS CELLE DU RIZ SUR BRÛLIS EN ALFISOL DANS DES CONDITIONS TROPICALES SEMI-ARIDES}

\author{
RÉSUMÉ
}

Des études ont été menées sur sol argilo-sablonneux (Haplustalf) pour évaluer l'influence de cinq conduites avec quatre régimes d'irrigation: irrigation de $60 \mathrm{~mm}$ à $\mathrm{W} / \mathrm{CPE}=0.6,0.8,1.0$ and 1.2 , et leur interaction sur les modifications de structure du sol et la performance du tournesol (Helianthus annuus L.) dans des conditions de jachère après une culture de riz. Le labour a en général un effet plus favorable que le "zéro labour" sur la levée, la croissance et 
le rendement du tournesol. Un premier labour profond avec des disques ou des soc MB a produit des capitules significativement plus grands avec un "test weight" plus élevé; toutefois un labour secondaire avec le rotavator a produit un lit de semences plus fin et a conduit à une levée plus élevée [80.7\%). Une façon culturale avec les disques et le rotavator a donné le meilleur rendement $\left(1311 \mathrm{~kg} \mathrm{ha}^{-1}\right)$. L'irrigation à IW/CPE $=1.2$ a donné de meilleurs résultants que à $\mathrm{IW} / \mathrm{CPE}=0.6,0.8 \mathrm{ou}$ 1.0. L'utilisation de l'eau (ETa) par le tournesol a augmenté avec l'intensité du labour et de l'irrigation. L'efficacité d'utilisation de l'eau [WUE] a été meilleure pour les labours les plus intenses et au régime d'irrigation de IW/CPE $=0.8$. Le labour profond, en dehors du fait qu'il entraîne une économie d'eau de $18 \%$, se traduit par une augmentation de $24 \%$ du rendement en graines, en comparaison avec un labour peu profond. Les effets d'interaction mettent en évidence que la meilleure croissance et les meilleurs rendement en graines et en huile ont été obtenus lorsque le labour a été faite avec disque et rotavator, associé à un schéma d' irrigation à $\mathrm{IW} / \mathrm{CPE}=1.0 \mathrm{ou}$ 1.2. Le labour avec deux passages de socs suivi d'un passage de rotavator pour obtenir un lit de semence plus fin, et un schéma d'irrigation à $\mathrm{IW} / \mathrm{CPE}=1.2 \mathrm{a}$ donné des résultats significativement supérieurs aux pratiques courantes des agriculteurs. 